\title{
PENGARUH KONDISI KALSINASI PADA SINTESIS SENYAWA HYDROXYAPATITE
}

\section{Lisa Utami, Syukri Arief dan Novesar Jamarun}

\author{
Program Studi Pendidikan Kimia, Fakultas Tarbiyah dan Keguruan, Universitas Islam Negeri Sultan Syarif Kasim, \\ Riau, Indonesia \\ Jurusan Kima, FMIPA, Universitas Andalas,Padang 25163, Indonesia \\ E-mail: lazoelva_1154@yahoo.com
}

\begin{abstract}
ABSTRAK
Kalsium fosfat telah menjadi perhatian yang menarik dalam bidang medis dan kedokteran karena biocompatibilitynya yang baik dan struktur serta komposisi kimianya yang sama dengan fasa mineral jaringan keras manusia (tulang dan gigi). Penelitian ini difoukuskan untuk mempelajari faktor yang mempengaruhi morfologi dan komposisi fasa dari senyawa hydroxyapatite dengan menggunakan prekusor diammonium hydrogen phosphate sebagai sumber fosfat serta pengaruh kalsinasi pada suhu $200,400,600,800$ dan $1000^{\circ} \mathrm{C}$. Produk hidroxyapatite yang dihasilkan dikarakterisasi dengan FTIR, XRD, SEM dan TGA. Hidroxyapatite yang dihasilkan dengan variasi suhu kalsinasi mempengaruhi morfologi dan komposisi fasa dari senyawa kalsium fosfat yang dihasilkan. Fasa yang terbentuk sebelum sampel powder fosfat dikalsinasi dengan (NH4)2HPO4 sebagai sumber fosfat adalah $\mathrm{Ca} 2 \mathrm{P} 2 \mathrm{O} 7.2 \mathrm{H} 2 \mathrm{O}$ dengan ukuran kristal $67 \mathrm{~nm}$. Ketika sampel powder kalsium fosfat dikalsinasi pada temperatur $600^{\circ} \mathrm{C}$ fasa yang terbentuk dengan menggunakan (NH4)2HPO4 sebagai sumber fosfat adalah hydroxiapatite (HAP) dengan ukuran kristal 8,66 nm Dan ketika sampel dikalsinasi pada temperatur $1000^{\circ} \mathrm{C}$ fasa yang dihasilkan yaitu $\mathrm{Ca} 2 \mathrm{P} 2 \mathrm{O} 7$ dan $\mathrm{Ca} 3(\mathrm{PO} 4) 2$.
\end{abstract}

Kata kunci: hydroxyapatite, prekusor, kalsinasi.

\section{PENDAHULUAN}

Sumatera Barat merupakan salah satu wilayah di kepulauan Indonesia yang memiliki berbagai jenis bahan galian yang bernilai, salah satunya adalah batu kapur. Batu kapur terbentuk dan berasal dari proses sedimentasi tumbuhan atau hewan laut yang terjadi secara organik, mekanik atau kimiawi yang didominasi oleh mineral kalsit. Di bawah tekanan tinggi akan mengeras menjadi batuan dan karena proses alam seperti pergeseran maka akan timbul kepermukaan laut dan akan terangkat menjadi pegunungan batu kapur [1]. Daerah penghasil batu kapur di Sumatera Barat adalah Dusun Pauh Tinggi Nagari Halaban Kabupaten Lima Puluh Kota dengan potensi Batu kapur 507.760.000 ton, Bukit Sumanik Kabupaten Sijunjung dengan potensi batu kapur 348.260.000 ton, Simarasap Kabupaten Agam dengan potensi batu kapur 109.375.000 ton, Bukit Bagawan Desa Subarang Kabupaten Solok dengan potensi batu kapur 6.237.000 ton, Muaro Kiwai Kabupaten Pasaman Barat dengan potensi batu kapur 1.300.000 ton dan Bukit Tui Kota Padang Panjang dengan potensi batu kapur 9.200.000 m3 [2]. Padang
Panjang merupakan salah satu kota yang berpotensi untuk pengembangan industri batu kapur di Sumatera Barat, dengan kandungan unsur kimianya sebagai berikut: $\mathrm{CaO}(52,32-$ $57,45 \%), \quad \mathrm{MgO}(0,96-4,55 \%), \quad \mathrm{Fe}_{2} \mathrm{O}_{3} \quad(0,32-$ 2,47\%) dan $\mathrm{SiO} 2$ (ttd-1,52\%) [2]. Pada beberapa dekade terakhir, biomaterial kalsium fosfat telah diaplikasikan secara klinis untuk memperbaiki kerusakan tulang, penambahan tulang dan coating untuk implan tulang. Kalsium fosfat memiliki berbagai macam turunan diantaranya amorphous calcium phosphate (ACP), brushite atau dicalcium phosphate dehydrate (DCPD, $\mathrm{CaHPO}_{4} \cdot 2 \mathrm{H}_{2} \mathrm{O}$ ), monotite atau dicalcium phosphate anhydrous (DCPA, CaHPO4), octacalcium phosphate (OCP, $\left.\mathrm{Ca}_{8} \mathrm{H}_{2}\left(\mathrm{PO}_{4}\right) 6.5 \mathrm{H}_{2} \mathrm{O}\right)$, whitelockite atau tricalcium phosphate (TCP, $\quad \mathrm{Ca}_{3}\left(\mathrm{PO}_{4}\right) 2, \quad$ calcium pyrophosphate dehydrate $\left(\mathrm{CPPD}, \mathrm{Ca}_{2} \mathrm{P}_{2} \mathrm{O}_{7}\right)$ dan hydroxiapatite (HAP, $\left.\mathrm{Ca}_{10}\left(\mathrm{PO}_{4}\right) 6(\mathrm{OH})_{2}\right\urcorner$ [3]. Diantara turunan di atas, hydroxiapatite (HAP) adalah salah satu turunan kalsium fosfat yang mempunyai aplikasi yang cukup menarik dalam bidang kesehatan yaitu sebagai material pengganti bagi kerusakan gigi dan tulang. Hal ini 
dikarenakan kesamaan sifat kimia dan bentuk kristalnya dengan berbagai jaringan tulang vertebrata.

Berbagai teknik telah dikembangkan untuk mensintesis powder HAP, dua teknik utama untuk mensintesis powder HAP adalah metoda basah dan reaksi solid state. Metoda basah dapat dipisahkan menjadi tiga bagian yaitu pengendapan, teknik hidrotermal dan hidrolisis. Reaksi solid state biasanya memberikan produk yang stoikiometrik dan bentuk kristal yang baik tapi memerlukan temperatur yang relatif tinggi dan waktu pemanasan yang panjang. Pada teknik pengendapan, disamping biayanya murah, mudah untuk mengontrol komposisi dan karakteristik fisika dari powder. Untuk teknik hidrotermal biasanya menghasilkan material dengan tingkat kristalinitas yang baik dan rasio $\mathrm{Ca} / \mathrm{P}$ nya mendekati nilai stoikiometrik. [4]. Ukuran kristalnya berada pada range nanometer sampai millimeter. Setiap teknik mempunyai kelebihan dan kekurangan masing-masing. Untuk memperbaiki sifat material hydroxiapatite (HAP) dapat dilakukan pengontrolan parameter penting dari powder seperti bentuk dan ukuran partikel, distribusi partikel dan aglomerasi. Powder HAP nanokristal lebih disukai karena menunjukkan luas permukaan yang lebih besar. Ini dapat memperbaiki kemampuan sinterability dan meningkatkan kepadatan bahan yang berguna untuk mengurangi temperatur sintering [5].

Parameter reaksi seperti temperatur, $\mathrm{pH}$, perbandingan $\mathrm{Ca} / \mathrm{P}$ dan kosentrasi reagen sangat penting untuk mengontrol komposisi hydroxiapatite (HAP). Namun sulit untuk mendapatkan senyawa murni HAP dikarenakan kalsium fosfat mempunyai banyak turunan, dari banyak penelitian yang telah dilakukan, komposisi fasa dari kalsium fosfat dapat berubah dengan sedikit variasi perbandingan $\mathrm{Ca} / \mathrm{P}$, temperatur dan $\mathrm{pH}$ larutan. Menurut Deepak et al., fasa HAP ditemukan stabil sampai suhu kalsinasi $600^{\circ} \mathrm{C}$ dan diatas suhu ini HAP akan terdisosiasi menjadi fasa lain seperti tricalcium phosphate (Ca3(PO4)2 [TCP]), calcium pyrophosphate $(\mathrm{Ca} 2 \mathrm{P} 2 \mathrm{O} 7$ [CPP]) dan calcium hydrogen phosphate (CaHPO4 [CHP]). TCP ditemukan menjadi fasa utama di atas suhu $1000^{\circ} \mathrm{C}$ [6]. Okazaki et al juga menemukan bahwa pola XRD menjadi lebih tajam dengan meningkatnya temperatur, menunjukkan bahwa derajat crystallinity dari powder HAP meningkat dengan naiknya temperatur [5].

Dengan alasan inilah, pada penelitian ini dipelajari pengaruh kondisi kalsinasi pada senyawa turunan kalsium fosfat menggunakan metoda pengendapan. Perlakuan ini mungkin mempengaruhi morfologi dan komposisi fasa dari senyawa kalsium fosfat. Oleh karena itu penelitian ini sangat penting tidak hanya untuk industri tetapi juga di bidang kesehatan, karena pada umumnya dalam aplikasinya senyawa kalsium fosfat biasanya dikalsinasi pada temperatur tinggi dalam rangka untuk meningkatkan sifat mekanikal, kristalinitas dan sifat aktivitas katalis dari material ini [7]. Pada penelitian ini juga digunakan prekursor sebagai sumber fosfat yaitu diammonium hydrogen phosphate dengan sumber kalsium digunakan kalsium asetat murni dan kalsium asetat yang sumber kalsiumnya berasal dari pelarutan $\mathrm{CaO}$ hasil kalsinasi batu kapur dengan asam asetat.

Banyak penelitian yang telah dilakukan pada berbagai keramik kalsium fosfat dan komposisi fasa dapat berubah dengan sedikit variasi perbandingan $\mathrm{Ca} / \mathrm{P}$ begitu juga temperatur dan $\mathrm{pH}$ larutan. Kalsium fosfat biokeramik dipersiapkan dengan beberapa metoda yaitu metoda pengendapan dibawah kondisi konstan, hidrolisis, reaksi solid state pada temperatur tinggi dan metoda hidrotermal.

Hydroxiapatite (HAP) adalah salah satu mineral biocompatible yang sangat efektif dan ditemukan sebagai komponen utama dari tulang. HAP secara kimia mempunyai sifat yang sama dengan mineral yang terkandung dalam komponen tulang dan jaringan keras mamalia. Ini merupakan salah satu dari sedikit mineral yang dapat dikelompokkan sebagai bioaktif, yaitu suatu mineral yang dapat mendorong pertumbuhan tulang dan pengikatan tulang seperti pada ortopedik, aplikasi yang berhubungan dengan gigi dan maxillofacial. Hydroxiapatite membentuk suatu kristal dalam sistem hexagonal (grup ruang $\mathrm{P} 63 / \mathrm{m}$ ), dan kemudian menjadi monoclinic pada temperatur 
kamar jika stoikiometri. Data XRD menunjukkan pita yang sangat lebar mengindikasikan kristalinitas yang rendah. Kristal HAP dapat berbentuk seperti mata pisau, jarum, batang atau partikel equiaxed. HAP terdiri atas gugus kompleks apatite dengan gugus akhir hidroksil. Ion $\mathrm{OH}$ - dapat diganti dengan $\mathrm{F}-$. $\mathrm{Cl}-$, atau CO32-.

HAP secara termal merupakan senyawa yang tidak stabil, mudah terurai pada temperatur antara $800-1200^{\circ} \mathrm{C}$ tergantung pada stoikiometrinya. Menurut Deepak et al., powder HAP stabil sampai suhu kalsinasi $600^{\circ} \mathrm{C}$ dan diatas suhu ini HAP akan terdisosiasi menjadi fasa lain seperti TCP, CPP dan CHP. HAP telah sukses digunakan sebagai filler tulang, penyembuh estetis, pelapis dari implant tulang, filler dari komposit anorganik/polimer dan pembawa sel kultur. Selain itu juga digunakan sebagai adsorbents untuk pemisahan protein dan enzim, katalis untuk dehidrasi dan dehidrogenasi alkohol serta oksidasi metana [7].

Pada penelitian ini juga digunakan prekursor sebagai sumber fosfat yaitu diammonium hydrogen phosphate dengan sumber kalsium digunakan kalsium asetat murni dan kalsium asetat yang sumber kalsiumnya berasal dari pelarutan $\mathrm{CaO}$ hasil kalsinasi batu kapur dengan asam asetat.

\section{METODOLOGI PENELITIAN}

Alat. Alat-alat yang digunakan pada penelitian ini adalah peralatan gelas, kertas saring Wathman 41, desikator, pompa vakum, oven, furnace, pulvarizer, hot plate stirrer, magnetic bar, kertas pH, XRF (ARL8680S, totalbcement analyzer), XRD (Philip type pw 1710), FTIR (Perkin Elmer),TGA dan SEM (Jeol. JSM6360LA).

Bahan. Batu kapur, aquades sebagai pelarut, asam asetat $\left(\mathrm{CH}_{3} \mathrm{COOH}\right) 2 \mathrm{M}$, kalsium asetat $\left(\mathrm{Ca}\left(\mathrm{CH}_{3} \mathrm{COOH}\right)_{2}\right)$, diammonium hidrogen fosfat $\left(\left(\mathrm{NH}_{4}\right)_{2} \mathrm{HPO}_{4}\right)$, dan ammonium hidroksida $\left(\mathrm{NH}_{4} \mathrm{OH}\right) 1 \mathrm{M}$ sebagai pengatur $\mathrm{pH}$.

Pengambilan Sampel dan Kalsinasi. Sampel berupa batu kapur di ambil dari Bukit Tui
Padang Panjang. Sampel digiling halus menjadi powder dengan peralatan pulvarizer dengan ukuran partikel $90 \mu \mathrm{m}$, kemudian sampel dikalsinasi dalam furnace dengan suhu $1000{ }^{\circ} \mathrm{C}$ selama 1 jam, lalu sampel disimpan dalam desikator. Sampel selanjutnya dianalisis menggunakan XRF di PT. Semen Padang untuk mengetahui kadar $\mathrm{CaO}$ dalam sampel.

Proses Pelarutan CaO. Timbang sampel hasil kalsinasi $(\mathrm{CaO}) 2,8 \mathrm{~g}$, dimasukkan ke dalam erlenmeyer dan tambahkan $50 \mathrm{~mL}$ asam asetat 2M, lalu di stirrer kuat pada kecepatan $1000 \mathrm{rpm}$ dan di panaskan pada suhu $50{ }^{\circ} \mathrm{C}$ selama 1 jam sehingga $\mathrm{CaO}$ larut. Setelah $\mathrm{CaO}$ larut maka larutan disaring dengan kertas wathman 41 menggunakan pompa vakum sehingga di dapatkan larutan filtrat.

Proses pelarutan $\left(\mathbf{N H}_{4}\right)_{2} \mathrm{HPO}_{4}$. Timbang $3,96 \mathrm{~g}\left(\mathrm{NH}_{4}\right)_{2} \mathrm{HPO}_{4}$, kemudian di larutkan dalam $50 \mathrm{~mL}$ aquades.

Proses Pelarutan $\mathrm{Ca}\left(\mathrm{CH}_{3} \mathrm{COO}\right)_{2}$ murni. Timbang 7, $91 \mathrm{~g} \mathrm{Ca}\left(\mathrm{CH}_{3} \mathrm{COO}\right)_{2}$ murni kemudian di larutkan dalam $50 \mathrm{~mL}$ aquades.

Pencampuran larutan $\mathrm{Ca}\left(\mathrm{CH}_{3} \mathrm{COO}\right)_{2}$ dengan $\left(\mathrm{NH}_{4}\right)_{2} \mathbf{H P O}_{4}$. Tambahkan secara perlahan-lahan $50 \mathrm{~mL}$ larutan $\left(\mathrm{NH}_{4}\right)_{2} \mathrm{HPO}_{4} \mathrm{ke}$ dalam larutan $50 \mathrm{~mL}$ larutan $\mathrm{Ca}\left(\mathrm{CH}_{3} \mathrm{COO}\right)_{2}$ dengan menggunakan buret. Campuran di stirrer dengan kecepatan 1000 rpm selama 2 jam, pH campuran dijaga pada $\mathrm{pH}=9$ dengan menggunakan $\mathrm{NH}_{4} \mathrm{OH} 1 \mathrm{M}$.

Penyaringan dan Pencucian Endapan Kalsium Fosfat. Dari campuran yang homogen di dapatkan endapan kalsium fosfat. Endapan kalsium fosfat yang di dapat disaring dengan kertas wathman 41 menggunakan pompa vakum, kemudian endapan di cuci menggunakan aquades. Endapan ini dikeringkan dalam oven pada temperatur $100-115^{\circ} \mathrm{C}$ selama 3 jam, kemudian di kalsinasi dengan variasi temperatur $200^{\circ} \mathrm{C}, \quad 400^{\circ} \mathrm{C}, \quad 600^{\circ} \mathrm{C}, \quad 800^{\circ} \mathrm{C}$ dan $1000^{\circ} \mathrm{C}$ masing-masing selama 1 jam. 


\section{Karakterisasi Sampel Kalsium Fosfat.}

Analisis FTIR dilakukan sebagai analisis awal untuk mengidentifikasi senyawa kalsium fosfat yang terbentuk dengan melihat serapan senyawa pada daerah radiasi infrared 400-4000 $\mathrm{cm}^{-1}$. Energi yang diserap akan menyebabkan keadaan vibrasi tereksitasi. Setiap tipe ikatan menyerap radiasi infrared pada panjang gelombang yang berlainan dan memiliki karakteristik yang dapat dibedakan. Untuk senyawa kalsium fosfat ini yang diidentifikasi adalah vibrasi ikatan molekul $\mathrm{PO}_{4}^{-3}, \mathrm{CO}_{3}{ }^{2-}, \mathrm{P}_{2} \mathrm{O}_{7}$ dan $\mathrm{OH}^{-}$. Untuk melihat struktur kristal dari powder kalsium fosfat yang terbentuk diamati dengan XRD (X-Ray Difraction) dengan monokromator grafit radiasi $\mathrm{Cu} \mathrm{K} \alpha$. Dengan analisis XRD diketahui struktur dan ukuran kristal. Pemotretan dengan SEM dilakukan terhadap powder yang di dapat, dimana sepotong kecil sampel yang di lapisi dengan ermas kemudian di tempatkan dalam wadah dan di ukur dengan SEM sehingga akan diketahui kehomogenan dari powder melalui permukaan sampel yang diamati. Analisis Thermogravimetric atau TGA adalah jenis pengujian yang dilakukan pada sampel untuk menentukan perubahan-perubahan dalam berat dalam kaitannya dengan perubahan suhu.

\section{HASIL DAN PEMBAHASAN}

\section{Komposisi Bahan Baku Batu Kapur.}

Komposisi kimia yang terdapat dalam batu kapur menentukan kualitas dari batu kapur. Untuk itu dilakukan analisis dari batu kapur dengan menggunakan alat X-Ray Flourescence (XRF). Pada penelitian ini, sampel batu kapur yang digunakan berasal dari Bukit Tui Padang Panjang. Hasil analisis komposisi kimia batu kapur dengan menggunakan XRF ditunjukkan pada Tabel 1.

Tabel 1. Komposisi Kimia Bahan Baku Batu

\begin{tabular}{|c|c|}
\multicolumn{2}{|c}{ Kapur } \\
\hline Senyawa & Komposisi Kimia (\%) \\
\hline $\mathrm{CaO}$ & 53,15 \\
$\mathrm{SiO} 2$ & 2,70 \\
$\mathrm{Al} 2 \mathrm{O} 3$ & 0,87 \\
$\mathrm{MgO}$ & 0,75 \\
\hline
\end{tabular}

\begin{tabular}{|c|c|}
\hline Fe2O3 & 0,85 \\
*LOI & 42,55 \\
\hline
\end{tabular}

*Loss On Ignition/hilang pijar $\left(\mathrm{CO}_{2}\right)$

Hasil analisis XRF menunjukkan bahwa kandungan $\mathrm{CaO}$ dalam sampel batu kapur lebih dari 50\% sehingga dapat digunakan sebagai bahan dasar dalam pembuatan senyawa kalsium fosfat. Karena batu kapur yang memiliki kualitas yang baik itu adalah yang memiliki kandungan $\mathrm{CaO}$ minimal 50\% (Hassibi, 1993). Apabila persentase $\mathrm{CaO}$ dikonversikan berdasarkan kandungan oksida logam saja tanpa gas karbon dioksida, maka kandungan $\mathrm{CaO}$ dalam batu kapur adalah $91,60 \%$.

\section{Pembuatan Senyawa Kalsium Fosfat.}

Penelitian sintesis senyawa kalsium fosfat ini dilakukan dengan menggunakan metoda pengendapan. Metoda pengendapan merupakan suatu metoda pembentukan padatan dalam larutan melalui reaksi kimia. Bahan dasar yang digunakan dalam penelitian ini adalah $\mathrm{CaO}$ yang berasal dari batu kapur alam daerah Bukit Tui Padang Panjang sebagai sumber kalsium, diammonium hydrogen fosfat, asam asetat sebagai pelarut $\mathrm{CaO}$ dan amoniak yang berfungsi untuk mengatur $\mathrm{pH}$ larutan. Dalam penelitian ini dilakukan variasi sumber fosfat dan temperatur kalsinasi $\left(200,400,600,800\right.$ dan $\left.1000^{\circ} \mathrm{C}\right)$ dari senyawa kalsium fosfat.

Pembuatan larutan homogen dilakukan dengan melarutkan $\mathrm{CaO}$ dalam asam asetat, setelah didapatkan filtrat maka ditambahkan larutan diammonium hidrogen fosfat atau asam fosfat secara perlahan-lahan, dengan perbandingan $\mathrm{Ca} / \mathrm{P}$ nya $1,67, \mathrm{pH}$ larutan diatur 9 dengan menggunakan amoniak. Dalam penelitian ini dilakukan proses pelarutan diammonium hidrogen fosfat dengan filtrat dari kalsium asetat selama 2 jam dengan menggunakan stirrer, sehingga didapatkan larutan homogen berwarna putih. Larutan homogen yang telah didapatkan dicuci dengan air, kemudian disaring dengan vakum dan dikeringkan dengan oven pada suhu $100-115^{\circ} \mathrm{C}$. Setelah itu sampel dikalsinasi dengan variasi temperatur $200,400,600,800$ dan $1000^{\circ} \mathrm{C}$. Hasil kalsinasi yang diperoleh berupa powder halus yang berwarna putih. JumLah 
endapan dalam sintesis senyawa kalsium fosfat ini tidak berbeda jauh untuk masing-masing kalsinasi yang berbeda.

\section{Analisis Fourier Transform Infra Red (FTIR).}

Analisis FTIR ini digunakan untuk mengetahui gugus fungsi, komposisi kimia dan vibrasi ikatan dalam suatu senyawa. Analisis ini merupakan langkah awal untuk membuktikan apakah senyawa yang dihasilkan benar mengandung molekul yang diinginkan [8]. Vibrasi spektroskopi (FTIR) dapat memberikan informasi lingkungan kimia dari fosfat, molekul air dan ion hidroksida. Analisis FTIR ini dilakukan pada daerah $400-4000 \mathrm{~cm}^{-1}$.

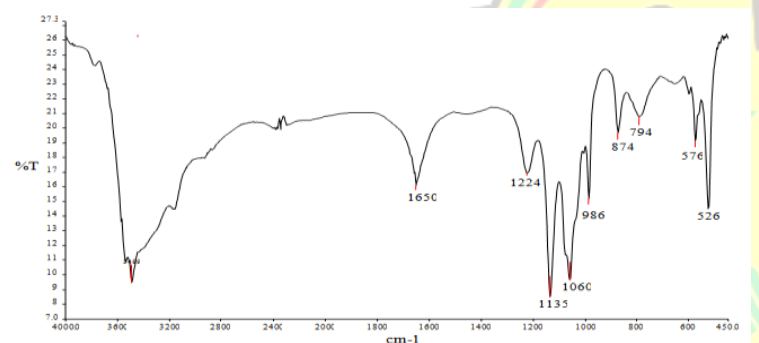

Gambar 1. Spektrum FTIR dari powder $\mathrm{Ca} / \mathrm{P}$ tanpa kalsinasi dengan $\left(\mathrm{NH}_{4}\right)_{2} \mathrm{HPO}_{4}$ sebagai sumber fosfat

Gambar 1 menunjukkan spektra FTIR dari powder kalsium fosfat tanpa kalsinasi dengan $\left(\mathrm{NH}_{4}\right)_{2} \mathrm{HPO}_{4}$ sebagai sumber fosfat. Pita pada 526 dan $576 \mathrm{~cm}^{-1}$ menunjukkan ikatan O-P-O bending mode $\left(\mathrm{v}_{4}\right)$ dan 986-1224 $\mathrm{cm}^{-1}$ menunjukkan asymmetric stretching mode $\left(\mathrm{v}_{3}\right)$. Pita pada $1650 \quad \mathrm{~cm}^{-1}$ dan $3489 \mathrm{~cm}^{-1}$ mengindikasikan kehadiran sejumLah air. Puncak kecil pada $874 \mathrm{~cm}^{-1}$ menunjukkan $\mathrm{HPO}_{4}$ yang mengkharak-terisasikan kalsium deficient apatite.

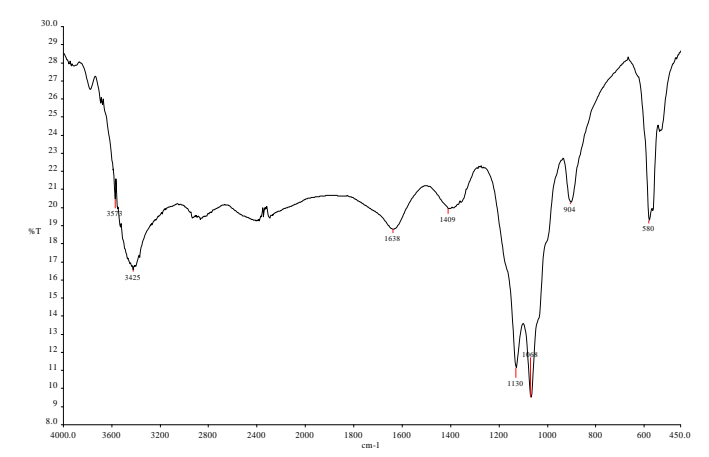

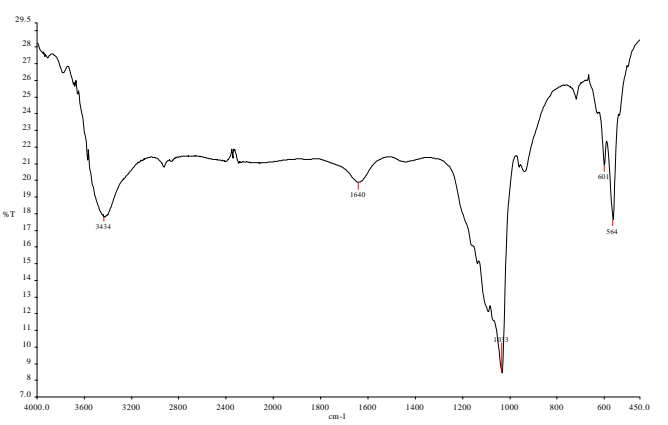
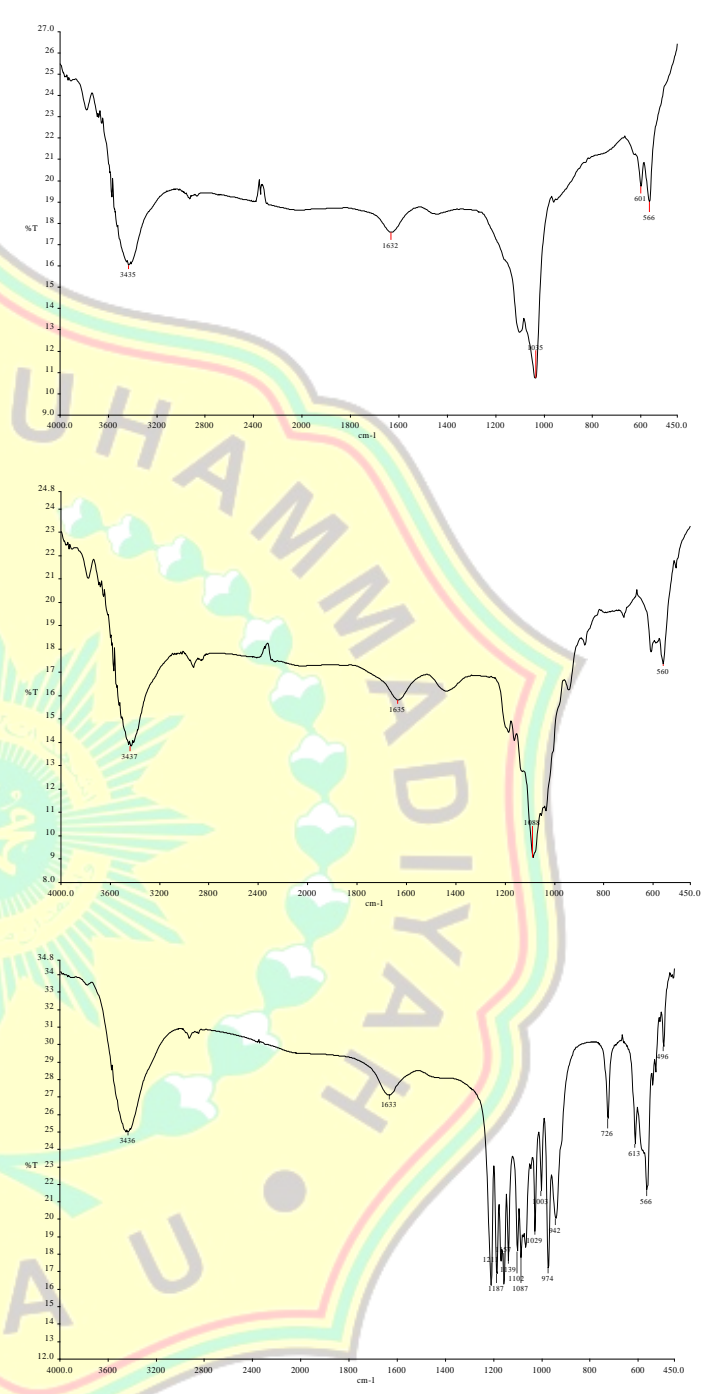

Gambar 2. Spektrum FTIR dari powder $\mathrm{Ca} / \mathrm{P}$ dengan variasi temperatur kalsinasi dengan $\left(\mathrm{NH}_{4}\right)_{2} \mathrm{HPO}_{4}$ sebagai sumber fosfat

Gambar 2 menunjukkan spektra FTIR dari powder kalsium fosfat yang dikalsinasi pada temperatur yang berbeda dengan $\left(\mathrm{NH}_{4}\right)_{2} \mathrm{HPO}_{4}$ sebagai sumber fosfat, yang memperlihatkan mode karakteristik vibrasi gugus $\mathrm{PO}_{4}{ }^{3-}, \mathrm{OH}^{-}$dan $\mathrm{P}_{2} \mathrm{O}_{7}{ }^{2-}$. Pita pada $560-580 \mathrm{~cm}^{-1}$ menunjukkan mode bending $\left(\mathrm{v}_{4}\right)$ dari O-P-O, 1003-1211 $\mathrm{cm}^{-1}$ 
menunjukkan mode stretching $\left(\mathrm{v}_{3}\right)$ asymetric dan 904-974 $\mathrm{cm}^{-1}$ menunjukkan simetric stretching vibrasi. Pita pada 1632-1638 $\mathrm{cm}^{-1}$ mengindikasikan sejumLah air $\left(\mathrm{H}_{2} \mathrm{O}\right)$. Pada kalsinasi $1000^{\circ} \mathrm{C}$, sebuah pita pada $726 \mathrm{~cm}^{-1}$ menunjukkan teramatinya grup pyrophosphate. Hal ini menunjukkan bahwa dengan meningkatnya temperatur kalsinasi, terjadi perubahan dari $\mathrm{CaHPO}_{4} .2 \mathrm{H}_{2} \mathrm{O}$ menjadi $\mathrm{Ca}_{2} \mathrm{P}_{2} \mathrm{O}_{7}$.

\section{Analisis Hasil X-ray Diffraction (XRD).}

XRD (X-Ray Diffraction) digunakan untuk mengetahui susunan atom-atom dalam suatu material kristalin sehingga dapat diketahui struktur, orientasi dan ukuran kristal [9]. Analisa XRD ini dilakukan untuk sampel dengan $\mathrm{H}_{3} \mathrm{PO}_{4}$ dan $\left(\mathrm{NH}_{4}\right)_{2} \mathrm{HPO}_{4}$ sebagai sumber fosfat tanpa kalsinasi, kalsinasi $600^{\circ} \mathrm{C}$ dan $1000^{\circ} \mathrm{C}$. Fasa yang dihasilkan sebelum dan sesudah kalsinasi dibandingkan dan diperkuat menggunakan standar JCPDS.

Gambar 3 memperlihatkan pola difraksi sinar $\mathrm{X}$ dari senyawa kalsium fosfat dengan $\left(\mathrm{NH}_{4}\right)_{2} \mathrm{HPO}_{4}$ sebagai sumber fosfat tanpa kalsinasi.

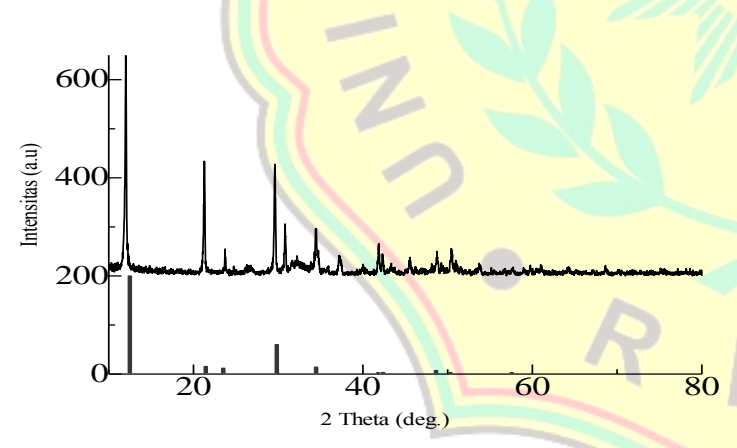

\section{Gambar 3. Pola XRD tanpa kalsinasi dengan $\left(\mathrm{NH}_{4}\right)_{2} \mathrm{HPO}_{4}$ sebagai sumber fosfat}

Pada gambar diatas puncak yang tajam dengan intensitas yang tinggi terdapat pada sudut $2 \theta=12,03^{\circ}$ dengan nilai hklnya $\left(\begin{array}{lll}1 & 0\end{array}\right)$, didukung oleh puncak-puncak pada sudut $2 \theta=29,61^{\circ}$; $21.32^{\circ} ; 34.46^{\circ} ; 41.87^{\circ} ; 50.48^{\circ} ; 48.76^{\circ} ; 23.75^{\circ}$; $42.34^{\circ}$ dan $57.67^{\circ}$ yang mirip dengan puncak dari JCPDS No. 70-0881. Berdasarkan data pada JCPDS no. 70-0881, maka produk yang terbentuk adalah $\mathrm{Ca}_{2} \mathrm{P}_{2} \mathrm{O}_{7} .2 \mathrm{H}_{2} \mathrm{O}$.
Pola difraksi sinar $\mathrm{X}$ juga dapat memberikan informasi mengenai ukuran kristal. Ukuran kristal ini bisa diketahui dengan metoda Scherrer, dimana puncak yang tajam dengan lebar puncak yang sempit menandakan bahwa ukuran kristal besar, sedangkan puncak yang mengalami pelebaran menandakan ukuran kristal kecil. Dengan mengukur FWHM (Full Width at Hall Maximum) dari puncak dengan refleksi tertinggi (Gambar 3), diperoleh ukuran kristalnya sebesar $67 \mathrm{~nm}$.

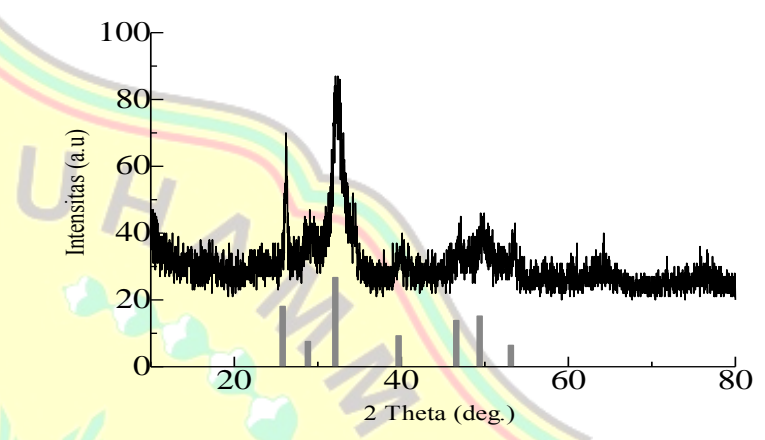

\section{Gambar 4. Pola XRD kalsinasi $6^{\circ}{ }^{\circ} \mathrm{C}$ dengan $\left(\mathrm{NH}_{4}\right)_{2} \mathrm{HPO}_{4} \quad$ sebagai sumber fosfat}

Pola difraksi dari powder kalsium fosfat yang dikalsinasi pada temperatur $600^{\circ} \mathrm{C}$ dengan $\left(\mathrm{NH}_{4}\right)_{2} \mathrm{HPO}_{4}$ sebagai sumber fosfat ditunjukkan pada gambar 4. Puncak difraksi maksimum terdapat pada sudut $2 \theta=32,21^{\circ}$ dengan merujuk kepada JCPDS No. 73-0293 maka nilai hklnya adalah ( $\left.\begin{array}{lll}1 & 1 & 2\end{array}\right)$. Puncak-puncak lain yang mendukung berada pada sudut $2 \theta=26,19^{\circ}$; $49,79^{\circ} ; 53,46^{\circ} ; 46,90^{\circ} ; 39,76^{\circ}$ dan $28,94^{\circ}$. Sesuai dengan data pada JCPDS No. 73-0293, maka produk yang dominan adalah hydroxiapatite $\mathrm{Ca}_{10}\left(\mathrm{PO}_{4}\right)_{6}(\mathrm{OH})_{2}$ dan tidak ada fasa kristalin lainnya yang terdeteksi, dengan ukuran kristal sebesar 8,66 nm.

Pola XRD dari powder yang dikalsinasi pada temperatur $1000^{\circ} \mathrm{C}$ diberikan pada gambar 5 . Puncak tajam dengan intensitas yang tinggi terdapat pada sudut $2 \theta=29,67^{\circ}$, dengan merujuk kepada JCPDS No. 70-0364 maka nilai hklnya (3 6 1). Hal ini didukung oleh puncak $2 \theta=26,73^{\circ}$ dan $32,07^{\circ}$, yang menunjukkan terbentuknya fasa $\mathrm{Ca}_{3}\left(\mathrm{PO}_{4}\right)_{2}$. 
Puncak yang lain juga terlihat pada $2 \theta=$ $28,95^{\circ}, 27,73^{\circ} ; 32,68^{\circ} ; 30,19^{\circ} ; 30,88^{\circ} ; 38,60^{\circ}$ dan $45.52^{\circ}$, dengan merujuk pada JCPDS No.20-0024 maka nilai hklnya $\left(\begin{array}{lll}2 & 0 & 3\end{array}\right)$ yang menunjukkan terbentuknya fasa $\beta-\mathrm{Ca}_{2} \mathrm{P}_{2} \mathrm{O}_{7}$.

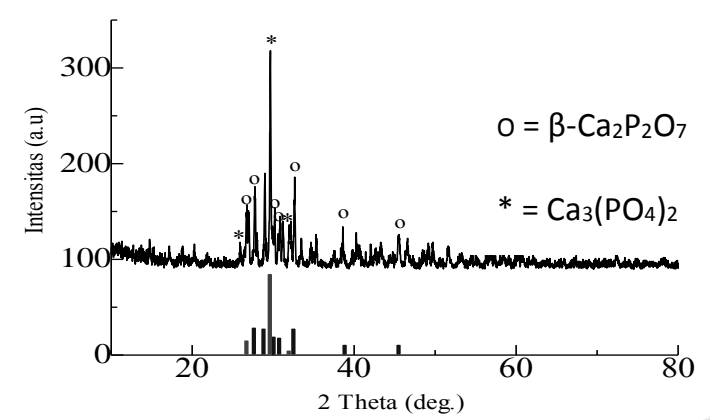

Gambar 5. Pola XRD kalsinasi $1000^{\circ} \mathrm{C}$ dengan $\left(\mathrm{NH}_{4}\right)_{2} \mathrm{HPO}_{4}$ sebagai sumber fosfat

Sesuai dengan data JCPDS No. 70-0364 dan No. 20-0024 maka fasa yang terbentuk setelah powder $\mathrm{CaP}$ dikalsinasi pada temperatur $1000^{\circ} \mathrm{C}$ adalah $\mathrm{Ca}_{3}\left(\mathrm{PO}_{4}\right)_{2}$ dan $\mathrm{Ca}_{2} \mathrm{P}_{2} \mathrm{O}_{7}$, dengan ukuran kristal 51,65 nm. Hasil XRD yang didapatkan ini sama dengan hasil penelitian yang dilakukan sebelumnya oleh Deepak, et at (2005), pada kalsinasi $1000^{\circ} \mathrm{C}$ terjadi perubahan komposisi fasa dari hydroxiapatite (HAP) menjadi tricalcium fosfat $\left(\mathrm{Ca}_{3}\left(\mathrm{PO}_{4}\right)_{2}[\mathrm{TCP}]\right)$ dan calcium pyrofosfat $\left(\mathrm{Ca}_{2} \mathrm{P}_{2} \mathrm{O}_{7}[\mathrm{TCP}]\right)$.

\section{Analisis SEM (Scanning Electron Microscopy). \\ SEM merupakan analisis yang digunakan} untuk mengkarakterisasi morfologi permukaan sampel. Karakterisasi dilakukan dengan cara menembaki permukaan sampel dengan elektron. Untuk karakterisasi SEM ini sampel kalsium fosfat yang dikarakterisasi hanya tiga buah saja yaitu sampel powder kalsium fosfat kalsinasi $600^{\circ} \mathrm{C}$ dan $1000^{\circ} \mathrm{C}$ dengan $\left(\mathrm{NH}_{4}\right)_{2} \mathrm{HPO}_{4}$ sebagai sumber fosfat dan sampel powder kalsium fosfat kalsinasi $600^{\circ} \mathrm{C}$ dengan $\mathrm{H}_{3} \mathrm{PO}_{4}$ sebagai sumber kalsium fosfat.

Pengukuran SEM ini dibuat dengan empat jenis pembedaran yaitu 1500x, 6500x, 10.000x dan 20.000x. Pada gambar 6, hasil SEM dari partikel hydroxiapatite memperlihatkan bentuk spheric atau seperti bola, dengan ukuran panjang partikel $14,07 \mu \mathrm{m}$ dan lebar $11,85 \mu \mathrm{m}$.

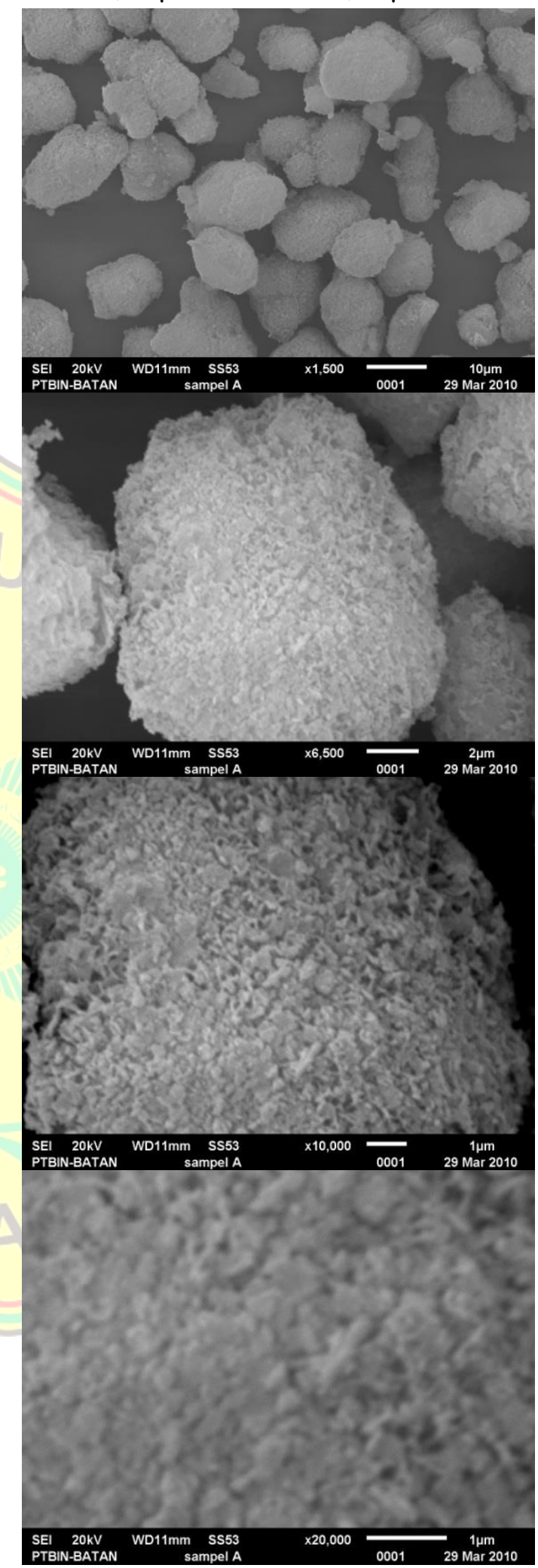

Gambar 6. SEM powder kalsium fosfat

kalsinasi $600{ }^{\circ} \mathrm{C}$ dengan $\left(\mathrm{NH}_{4}\right)_{2} \mathrm{HPO}_{4}$ sebagai sumber fosfat 


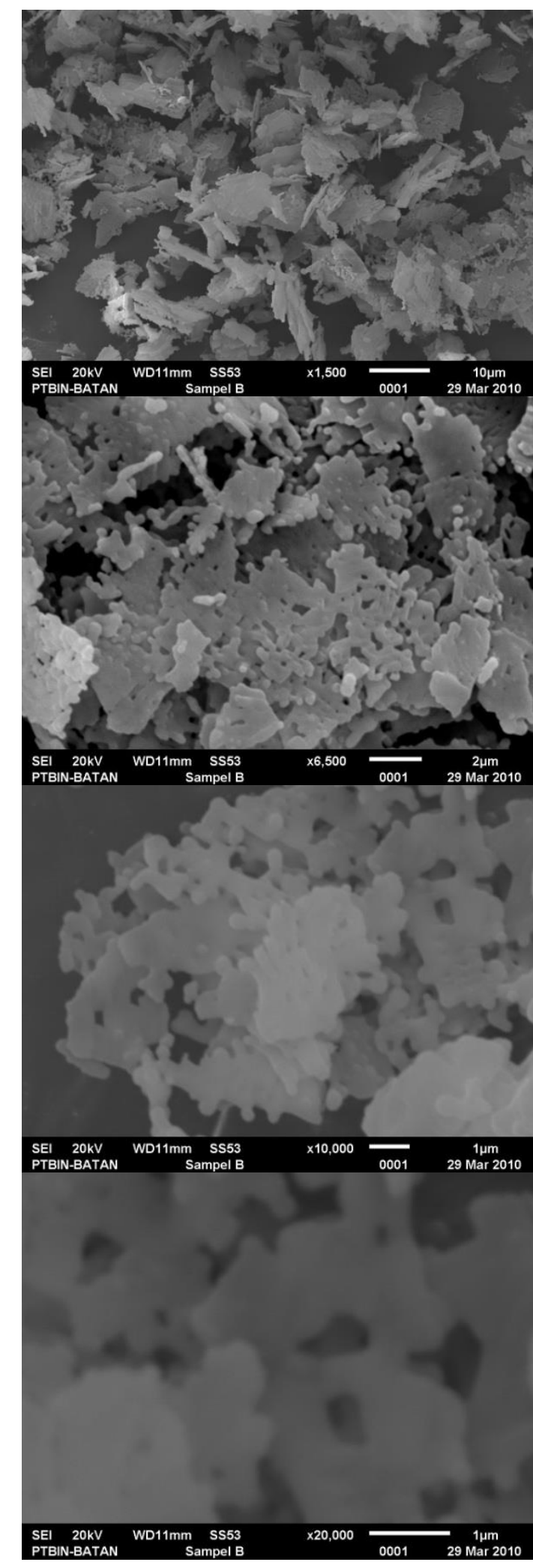

Gambar 7. SEM powder kalsium fosfat kalsinasi $1000^{\circ} \mathrm{C}$ dengan $\left(\mathrm{NH}_{4}\right)_{2} \mathrm{HPO}_{4}$ sebagai sumber fosfat

Gambar 7 menunjukkan gambar SEM dari powder kalsium fosfat yang dikalsinasi pada temperatur $1000^{\circ} \mathrm{Cdengan}\left(\mathrm{NH}_{4}\right)_{2} \mathrm{HPO}_{4}$ sebagai sumber fosfat. Dari gambar terlihat gumpalan partikel yang tidak sama besar dengan panjang partikel 4,05 $\mu \mathrm{m}$ dan lebar $3 \mu \mathrm{m}$. Hal ini mungkin saja berhubungan dengan temperatur kalsinasi dimana dengan meningkatnya temperatur akan meningkatkan aktivitas pertumbuhan partikel sehingga partikel memiliki kecendrungan untuk bergabung membentuk gumpalan sehingga terjadi penurunan area permukaan. Hasil SEM yang didapatkan ini sama dengan penetian hasil penelitian sebelumnya yang dilakukan oleh D.R.R. lazar,et al, dimana powder yang dikalsinasi pada temperatur $1000^{\circ} \mathrm{C}$, teramati gumpalan partikel dengan ukuran yang hampir sama, dimana menurutnya pada kalsinasi $1000^{\circ} \mathrm{C}$ dimulai peningkatan ukuran partikel sehingga terjadi penurunan area permukaan spesifik [10].

\section{Analisis TGA-DTA.}

Gambar kurva TGA-DTA dari sampel kalsium fosfat dengan $\left(\mathrm{NH}_{4}\right)_{2} \mathrm{HPO}_{4}$ sebagai sumber fosfat setelah dikeringkan. Dari kurva TGA dapat diamati terjadi kehilangan berat dimulai dari temperatur 100 sampai $800^{\circ} \mathrm{C}$ yang dapat diasumsikan lepasnya molekul air yang terserap oleh powder kalsium fosfat. Dari kurva DTA terlihat puncak pada temperatur $200^{\circ} \mathrm{C}$ yang menunjukkan mulai terjadinya perubahan fasa.

\section{KESIMPULAN}

Berdasarkan penelitian yang telah dilakukan, maka diperoleh kesimpulan bahwa variasi kalsinasi mempengaruhi morfologi dan komposisi fasa dari senyawa kalsium fosfat yang dihasilkan. Fasa yang terbentuk sebelum sampel powder fosfat dikalsinasi dengan $\left(\mathrm{NH}_{4}\right)_{2} \mathrm{HPO}_{4}$ sebagai sumber fosfat adalah $\mathrm{Ca}_{2} \mathrm{P}_{2} \mathrm{O}_{7} \cdot 2 \mathrm{H}_{2} \mathrm{O}$ dengan ukuran kristal $67 \mathrm{~nm}$ Ketika sampel powder kalsium fosfat dikalsinasi pada temperatur $600^{\circ} \mathrm{C}$ fasa yang terbentuk dengan menggunakan $\left(\mathrm{NH}_{4}\right)_{2} \mathrm{HPO}_{4}$ sebagai sumber fosfat adalah hydroxiapatite (HAP) dengan ukuran kristal 8,66 nm Dan ketika sampel dikalsinasi pada temperatur $1000^{\circ} \mathrm{C}$ fasa yang dihasilkan yaitu $\mathrm{Ca}_{2} \mathrm{P}_{2} \mathrm{O}_{7}$ dan $\mathrm{Ca}_{3}\left(\mathrm{PO}_{4}\right)_{2}$. 


\section{DAFTAR KEPUSTAKAAN}

Oates, T.1990. Lime and Limestone. In Ullmans Encyclopedia of Industrial Chemistry. Vol 15, Germany. pp:247-261. [1]

Dinas Energi dan Sumber Daya Mineral Propinsi Sumatera Barat. 2008. Informasi Potensi Sumber Daya Mineral dan Energi Propinsi Sumatera Barat. Hal. 1-5. [2]

Shaobing Zhou, Qiuxiang Su, Xiaohong Li, Jie Weng. 2006. A Novel in Situ Synthesis of Dicalcium phosphate Dehydrate Nanocrystals in Biodegradable Polymer Matrix. Material Science and Enginering. Pp: 341-345. [3]

Jae-Kil Han, Ho-Yeon Song, Fumio Saito, Byong-Taek Lee. 2006. Synthesis of High Purity Nanosized Hydroxiapatite Powder by Microwave- Hydrothermal Methods. Material Chemistry and Physics. Pp: 235239. [4]

Mobasherpour, I. M. Soulati Heshajin, A. Kazemdeh, M. Zakeri. 2007. Synthesis of Nanocrystalline Hydroxiapatite by Using Precipitation Method. Journal of Alloys and Compounds. pp: 330-337. [5]

Deepak K. Pattanayak, Rajalaxmi Dash, R. C.
Prasad, B.T. Rao, T.R. Rama Mohan. 2006. Synthesis and Sintered Properties Evaluation of Calcium phosphate Ceramics. Department of Metallurgical and Materials Science, Indian Institute of Technology, Bombay, Mumbai, 400076, India. [6]

Hidekazu Tanaka, Masatoshi Chikazawqa, Kazuhiko Kandori and Tatsuo Ishikawa. 2000. Influence of Thermal Treatment on The Structure of Calcium Hydroxiapatite. [7]

"Fourier Transform Infrared Spektroscopy", http: //info-wcas@bodycote.com, (14/06/2008). [8]

Weller M. T. 1994. Inorganic Material Chemistry, Oxford University Press, Tokyo, pp 15-25. [9]

D. R. R. Lazar, S. M. Chunha., V Ussui., E. Francio., N.B. deLima., A.H.A. Bressiani. 2006. Effect of Calcination Conditions on Phase Formation of Calcium phosphates Ceramics Synthesized by Homogenous Precipitation. Materials Science Forum. Vols 530-531. pp: 612-617. [10] 